\title{
Miracle of Herbals and Natural Products in Treatment and Regulation of Obesity
}

\author{
Himangshu Jyoti Hazarika1, Aziz Ahmed², Kaushal K. Chandrul³ \\ 1Pharmacy Graduate, ${ }^{2}$ Assistant Professor and Researcher, ${ }^{3}$ Faculty of Research and Development, \\ 1,2,3 Mewar University, Chittorgarh, Rajasthan, India
}

\begin{abstract}
How to cite this paper: Himangshu Jyoti Hazarika | Aziz Ahmed | Kaushal K. Chandrul "Miracle of Herbals and Natural Products in Treatment and Regulation of Obesity" Published in International Journal of Trend in Scientific Research and Development (ijtsrd), ISSN: 24566470, Volume-3 | Issue-4, June 2019, pp.83-92, URL: https://www.ijtsrd.c om/papers/ijtsrd23 549.pdf

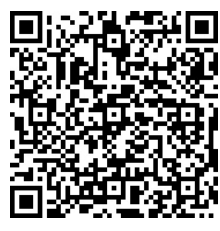
IITSRD23549
\end{abstract}

Copyright (C) 2019 by author(s) and International Journal of Trend in Scientific Research and Development Journal. This is an Open Access article distributed under the terms of the Creative Commons

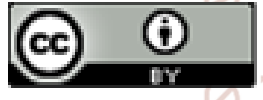
Attribution License (CC BY 4.0) (http://creativecommons.org/licenses/ by $/ 4.0$ )

(for example stroke, osteoarthritis, rest apnea, diseases, and irritation based pathologies). $(3,4)$ According to considers in distinctive nations, a large individual brings about social insurance uses at any rate $25 \%$ higher than a solid person.(5)Adding generation misfortunes to human services costs, corpulence represents a extensive rate loss of total national output in most nations $(>1 \%$ in US, $>3.6 \%$ in China.(6) Weight could be iatrogenic, for example auxiliary to sedate medicines (antipsychotic, energizer, antiepileptic, steroids, and insulin), or because of specific illnesses (Cushing disorder, hypothyroidism, and hypothalamic defects).(7) Obesity as an essential issue pursues a positive vitality balance. The recognizable proof of the essential drivers of this unevenness remain testing and includes most of cases typically analyzed after reasons for auxiliary stoutness are ruled out.8 This unending malady results from complex connections of hereditary, conduct, and ecological variables corresponding with monetary and economic wellbeing and lifestyles.(9)truth be told, heftiness is more visit in populaces living in conditions described by a long haul vitality positive lopsidedness because of stationary way of life, low resting metabolic rate, or both.(10) Causes of weight include qualities, digestion, diet, physical action, and the socio-social condition that describes 21 st century living style.(11) The distinguishing proof of potential sub-atomic targets vulnerable to be controlled from outside elements, especially nourishment and medication operators may help individuals in picking up control over craving permitting heftiness aversion. Healthful genomics could figure out which explicit supplements bring phenotypic changes that impact the heftiness chance and could build up which connections are the most important.(12) Worldwide systems are centered around dietary and way of life changes, for example limit calorie admission and increment physical action to moderate weight development.(13) Researches showed the capability of regular items to check obesity.(14) Multiple characteristic item blends may result in a synergistic action that expands their bioavailability and activity on numerous atomic targets, offering points of interest over substance treatments.(15,16 )The counter corpulence impacts of these mixes are interceded by guideline of different pathways, counting lipid assimilation, vitality admission and consumption, expanding lipolysis, and diminishing lipogenesis, separation what's more, expansion of preadipocytes.(15)

\section{DEFINATION}

The word weight originates from the Latin obesitas, which implies forceful, fat, or stout. Restoratively, weight is a condition in which abundance muscle to fat ratio has collected to the degree that it might have an unfavorable 
impact on wellbeing, prompting decreased future and additionally expanded wellbeing problems.(17)

\section{HOW TO ASSESS OBESITY?}

Body weight is definitely not a decent pointer as it doesn't recognize among fat and bulk. Different measures, including weight file (BMI) and Waist to Hip Ratio (WHR) have been created to recognize those in danger of genuine wellbeing issues.

\subsection{Body mass index (BMI)(18)}

Body mass list could be a estimation which connects weight and tallness: $\mathrm{BMI}=$ Mass $(\mathrm{kg}) /[$ Height $(\mathrm{m})] 2$. Table 1 records the BMI values agreeing to the WHO information which have been distributed in 2000

\begin{tabular}{|c|c|}
\hline Classification & BMI \\
\hline Under weight & $<18.5$ \\
\hline Normal weight & $18.5-24.9$ \\
\hline Over weight & $25-29.9$ \\
\hline Class I obesity & $30-34.9$ \\
\hline Class II obesity & $35-39.9$ \\
\hline Class III obesity & $40 \geq$ \\
\hline
\end{tabular}

Table1. BMI values according to the WHO data

\subsection{Waist Circumference (WC) and Waist to Hip Ratio (WHR)(19)}

WHR is utilized as a estimation of corpulence, which in turn is a possible pointer of other more genuine wellbeing conditions, WHO states that stomach corpulence is characterized as a waist-hip ratio over 0.90 for guys and over 0.85 for females. Women with waist-hip proportions of more than 0.8 , and men with more than 1.0 , are at expanded wellbeing chance since of their fat conveyance. WHR has been appeared to be distant better; a much better;a higher;a stronger;an improved">a much better indicator of cardiovascular infection than Abdomen Circumference and body-mass index.(19)

WHR is more later prove, which bargains with the central distribution of body fat as an marker of wellbeing dangers. Waist distribution of fat has been evaluated by calculating the waist/ hip ratio.

WHR $1 / 4$ Midriff Circumference=Hip circumference

\section{CAUSES OF OBESITY}

At person level, the combination of intemperate nourishment energy intake and need of physical movement is thought to clarify most of weight causes.(20) In constrained cases, weight is due to genetic factors, therapeutic reasons, or psychiatric illness.(21) On the other hand, expanding rates of weight at a societal level are felt to be due to effortlessly open and agreeable slim down, expanded reliance on cars, and mechanized manufacturing.(22) A 2006 survey distinguished ten other conceivable supporters to the later increment of obesity counting inadequately rest, endocrine disruptors, challenging and comprises the lion's share of cases more often than not analyzed after causes for auxiliary weight are ruled out.(8) This chronic illness comes about from complex intuitive of genetic, behavioral, and natural variables connecting with financial and social status and lifestyles.(9) In truth, corpulence is more frequent in populaces living in situations characterized by a long-term vitality positive lopsidedness due to sedentary l diminished inconstancy in encompassing temperature, diminished rates of smoking, as smoking smothers craving, expanded utilize of medication that can cause weight pick up (e.g., atypical antipsychotics), relative increments in ethnic and age bunches that tend to be heavier, pregnancy at a afterward age (which may cause susceptibility to corpulence in children), epigenetic hazard factors passed on generationally, common choice for higher BMI, and assortative mating driving to expanded concentration of obesity chance factors.(23)

\subsection{Diet}

Weight rates within the US (1971-2000) expanded from $14.5 \%$ to $30.9 \% .24$ Amid the same period, there was an increment in the average sum of nourishment devoured (normal increment for women 335 and 168 cal./day). Most of this additional nourishment energy was due to the increase in carbohydrates instead of fat consumption.(24)

\subsection{Sedentary lifestyle}

There's a huge move toward less physically requesting work worldwide. As of now, at slightest $60 \%$ of the world's population gets deficiently work out, due to expanded utilize of mechanized transportation and a more noteworthy predominance of labor-saving innovation at home.(25) The WHO shows individuals around the world are taking up less dynamic recreational interests. In both children and grownups, there's an affiliation between tv viewing time and the hazard of obesity.(26)

\subsection{Genetics}

Like numerous other therapeutic conditions, weight is the result of interplay between hereditary and natural components. Polymorphisms in different qualities controlling craving and metabolism predispose to corpulence when adequate nourishment vitality is present. People with two duplicates of the FTO quality (fat mass and obesity associated quality) have been found on normal to weigh 3-4 kg more and have a 1.67 overlay more prominent chance of corpulence compared to those without the hazard allele.(27) A few cases of weight are related to single-gene changes, e.g. melano-cortin-4 receptor (MC4R) gene(28), dopamine receptor D4 (DRD4)(29), peroxisome proliferatoractivated receptor y2 (PPARy2)(30) or the leptin genes.(31)

\subsection{Medical and psychiatric illness}

Certain physical and mental ailments and drugs utilized to treat them can increment the chance of corpulence. Therapeutic illnesses that increment weight hazard incorporate a few uncommon hereditary disorders (Cohen disorder), as well as a few innate or acquired conditions: hypothyroidism, development hormone deficiency,(32) and eating clutters (orgy eating clutter and night eating syndrome).(33) The hazard of overweight and weight is higher in patients with psychiatric disarranges than in persons without psychiatric disorders.(34)

\subsection{Social determinants}

Hereditary impacts are imperative to get it corpulence. They cannot clarify the current sensational increment in obesity. Though, overabundance vitality utilization than vitality expenditure leads to weight on person premise. The cause of the shifts in these two variables on societal scale is much debated.(35) In creating nations ladies of a tall social lesson were less likely to be stout. No noteworthy contrasts were seen among men of different social classes. Within the creating world, population of tall social classes had more prominent rates of obesity.(36) Smoking has a noteworthy impact on an individual's weight. Those who quit smoking will pick up an normal of $4.4 \mathrm{~kg}$ (men) and $5.0 \mathrm{~kg}$ (women) 
over ten a long time. Be that as it may, changing rates of smoking have small impact on the by and large rates of obesity.(37)

\subsection{Infectious agents}

The ponder of irresistible agent's impact on digestion system is still in its early stages. The intestine vegetation in corpulent and incline people can affect the metabolic potential. This clear modification is believed to bestow a more prominent capacity to pick up vitality contributing to corpulence. An affiliation between infections and weight has been found in people and a few distinctive creature species.(38)

\subsection{Pathophysiology}

Leptin and ghrelin are inside go betweens that influence feeding and craving. Ghrelin is created by the stomach modulating short-term appetitive control (i.e., to eat when the stomach is empty and to halt when the stomach is extended). Leptin is produced by white fat tissue to flag fat capacity saves within the body and intervenous long-term appetitive controls (i.e., to eat more when fat storages are low and less when fat stockpiles are tall). It plays a basic part within the direction of bodyweight and vitality adjust by restraining nourishment admissions and fortifying vitality expenditure.(39) In spite of the fact that, organization of leptin may be viable in a little subset of stout people who are leptin lacking. Most stout people are thought to be leptin safe and have been found to have tall levels of leptin.(40) This resistance is thought to clarify in portion why organization of leptin has not been appeared to be successful in suppressing craving in most hefty people.(41) 1 In spite of the fact that leptin and ghrelin are delivered incidentally, they control appetite through their activities on the central apprehensive framework. In this way, a deficiency in leptin signaling either through leptin insufficiency or leptin resistance leads to overloading and may account for some genetic and procured shapes of obesity. $(41,42)$

\section{PATHOLOGIES ASSOCIATED WITH OBESITY AND ITS EFFECT ON HEALTH :}

In expansion to, mechanical impacts on the body (i.e., compounding osteoarthritis and back torment due to additional weight) since of the additional weight set on the skeleton, corpulence is related with the next frequency of a few pathologies.

\subsection{Diabetes mellitus}

Amassed information illustrate the affiliation between obesity and noninsulin-dependent diabetes mellitus, which is the most common essential shape of diabetes and disabled glucose tolerance. In hefty people, fat tissue discharges high amounts of non-esterified greasy acids, glycerol, proinflammatory cytokines, and hormones. They are connected with the improvement of affront resistance, which produce compensatory hyperinsulinemia with overstimulation of pancreatic cells and reduction of affront receptors.(43)

\subsection{Hypertension}

Epidemiological thinks about have illustrated that 65-75\% of the chance of hypertension is accounted for by obesity.(44) Endocrinological considers of the fat tissue uncovered joins between corpulence and hypertension, likely resulting to the reality that the fat tissue secretes bioactive atoms and immunomodulators.(45)

\subsection{Dislipidemia}

Obesity is the foremost common cause of dislipidemia. Lipid oversupply in a state of obesity, hyperinsulinemia, and/or affront reandsistance comes about in expanded nonesterified greasy corrosive accessibility , in turn, higher TG stores in non-adipose tissues, e.g. the muscle, liver, and pancreas.(46,47) Greasy acid-induced disarranges are alluded to as lipotoxicity. Hence, lifted TG level isoften went with by a slight increment in add up to cholesterol anda stamped drop in high-density lipoprotein (HDL) cholesterol.Moreover, low-density lipoproteins (LDL) wealthy in TG, mostly metabolized by hepatic lipase, are changed over into smallLDL, with higher atherogenic potential.(48)

\subsection{Cardiac alterations}

Weight increments the chance of heart disappointment, sudden cardiac death, angina or chest torment, and irregular heart rhythm.(49) Increased electrical modifications in corpulence lead to visit ventricular dysrhythmias indeed within the nonappearance of heart dysfunction. The yearly sudden cardiac passing rate was about 40 times higher in corpulent individuals than in non corpulent population.(50)

\subsection{The metabolic syndrome}

Obesity is the major component of the metabolic syndrome (multiple metabolic clutters). This disorder is characterized by the co-occurrence of numerous metabolic disarranges, namely overall and stomach weight, affront resistance, hypertension, hyperglycemia, disabled glucose resilience, and the combination of moo HDL cholesterol and lifted TG level.(51)

\subsection{Lung diseases}

Obesity is related with an expanded chance of unremitting respiratory disarranges (e.g. asthma, hypoventilation disorder, and rest apnea). In like manner, weight misfortune regularly leads to symptomatic improvement.(52)

\subsection{Cancer}

The connect between count calories, obesity, and cancer isn't completely understood, but the rising world-wide drift in obesity and cancer may be at slightest in portion causal. The putative cause of these obesity-related cancers has been fundamentally credited to excess estrogen generation by the fat tissue, inflammation due to adipocytokines discharged by adipocytes, penetrating macrophages or related stromal cells that might moreover play an important role. $(53,54)$

\subsection{Neurological disorders}

Mental harm caused by overweight and obesity ranges from brought down self-esteem to straight to the point clinical depression. Indeed, rates of uneasiness and sadness are three to four times higher among hefty individuals.(55)Obesity significantly increases the hazard of Alzheimer's malady. A solid correlation exists between BMI and tall levels of amyloid, i.e. the protein that amasses within the Alzheimer's brain, wrecking nerve cells and creating cognitive and behavioral problems.(56)

\subsection{Treatment of obesity}

Eat less, work out, pharmacotherapy, behavioral treatment, and way of life alteration each can deliver a unassuming weight misfortune within the extremely corpulent. Pharmacotherapy, in expansion to count calories and work out, has been illustrated to encourage a weight misfortune of 2-10\% per year.(57) Long-term upkeep of significant weight 
loss, continues to be the foremost challenging issue in the restoratively based treatment for over weight.

\section{PREVENTION OF OBESITY}

As a result of the later exponential increment in weight, the American Heart Affiliation has discharged a few guidelines for distinguishing proof and early intercession for both grown-up and adolescent weight gain.(58) Losing weight can invert the hurtful wellbeing impacts

credited to abundance weight, and may progress or anticipate obesity-related diabetes mellitus, dyslipidemia, hypertension, and diastolic cardiac dysfunction.(59).

\subsection{Dietary intervention}

Clusters of diets have been proposed for weight misfortune in obese patients. . The proposed weight loss programs included an in individual center-based program, a telephonebased weight misfortune counseling program, and a control bunch of "usual care". The regular care gather gotten individualized weight misfortune counseling sessions and month to month contacts; be that as it may they did not get free prepackaged suppers. The patients partaking within the center and telephone-based bunches were given with prepackaged nourishment things and a arranged menu. They were empowered moreover to form behavioral changes with respect to physical activity.(60)

\subsection{Diet control}

The day by day prerequisites of people with direct physical activity shift with age and sex, (3200-2550 kcal for males in calm climate and 2300-1800 kcal for females). 800-1000 $\mathrm{kcal} /$ day ranges are habitually utilized in weight diminishment programs. Fasting or semi-starvation is some of the time proposed as a cruel of weight lessening in obesity.(61) Sustenance instruction is imperative for weight administration (e.g., low-fat nourishment may still cause weight pick up, since both protein and carbohydrates can be metabolically changed over to fat). Moo calorie diets $(<1200$ $\mathrm{kcal} /$ day) and exceptionally moo calorie diets $(<800$ kcal/day) may be related with different impacts such as expanded uric corrosive level, expanded chance of bother stone arrangement, misfortune of lean body mass, electrolyte unsettling influences and mellow liver dysfunction.(62)

\subsection{Physical activity}

Weight pick up and weight are reactions to long term positive energy adjust where: Energy Adjust 1/4 Vitality Admissions Vitality Expenditure Energy adjust includes harmony between calorie intake and vitality utilization (physical action, basal digestion system, and adaptive thermogenesis).(63) The advancement of overweight and corpulence may be a result of the simple and cheap availability of high-calorie nourishments, which is combined with inactive way of life (Fig. 1). A assortment of works out such as strolling, cycling, swimming, and high impact exercise are compelling and simple to implement. Regular physical action is an fundamental component to lose weight. To lose weight, one must accomplish a negative vitality adjust (i.e., diminished vitality admissions and expanded vitality use). Overweight patients who take part in at slightest 30 min of direct physical movement most days of the week, or who have direct to tall cardio-respiratory wellness have decreased all-cause mortality than those who are sedentary and un-fit. $(64,65)$

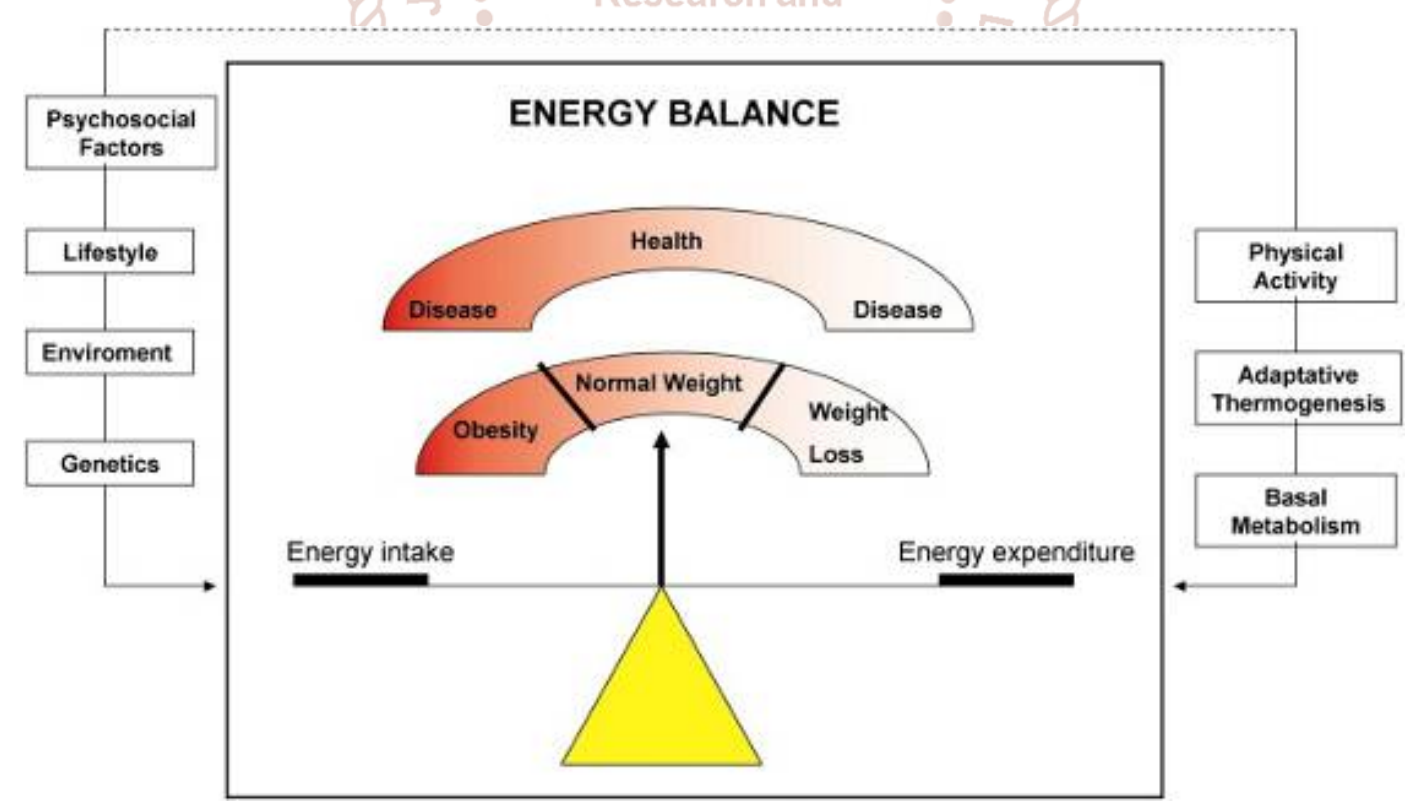

Figure 1 Fundamental principles of energy balance

\subsection{Pharmacotherapy}

Medicines can encourage weight misfortune in stout people. Comparative tonecessary to endorse pharmacotherapies. The understanding must have a BMI more noteworthy than $30 \mathrm{~kg} / \mathrm{m} 2$ or BMI of at slightest $27 \mathrm{~kg} / \mathrm{m} 2$ with obesity-related comorbidities. Drugs are frequently required long-term as numerous people recapture weight when they are suspended. In expansion, person's compliance to these daily drugs is of concern, particularly in light of cost, potential need of protections scope, and conceivable side impacts. Another course of anti-obesity medications smothers craving by expanding the level of neurotransmitters at the neural connection intersection, where starvation and fullness (satiety) are directed by brain neurotransmitters (e.g., serotonin, norepinephrine, and dopamine). A few common solutions for weight misfortune are recorded in Table 2. (66-67). 
International Journal of Trend in Scientific Research and Development (IJTSRD) @ www.ijtsrd.com eISSN: 2456-6470

\begin{tabular}{|c|c|c|c|}
\hline Drug & Mechanism of action & Effect on weight & Side effects \\
\hline $\begin{array}{l}\text { Phentermine } \\
\text { (Fastin) }\end{array}$ & Craving suppressant diminishes nourishment intake. & $\begin{array}{l}3.6 \mathrm{~kg} \text { at } \\
6 \text { months }\end{array}$ & $\begin{array}{l}\text { Headache, insomnia, } \\
\text { irritability, palpitation } \\
\text { and nervousness }\end{array}$ \\
\hline Diethylpropion & $\begin{array}{l}\text { Sympathomimitic amine causes discharge of } \\
\text { norepinephrine by the cells. }\end{array}$ & & \\
\hline $\begin{array}{l}\text { Fluoxetine } \\
\text { (Prozac) }\end{array}$ & $\begin{array}{l}\text { Diminishes nourishment admissions through } \\
\text { specific hindrance of serotonin re-uptake. }\end{array}$ & $\begin{array}{c}4.74 \mathrm{~kg} \text { at } \\
6 \text { months and } \\
3.15 \mathrm{~kg} \text { at } 1 \text { year } \\
\end{array}$ & $\begin{array}{l}\text { Agitation and } \\
\text { nervousness }\end{array}$ \\
\hline $\begin{array}{l}\text { Sibutramine } \\
\text { (Xencial) }\end{array}$ & $\begin{array}{l}\text { Diminishes nourishment admissions through } \\
\text { combined norepinephrine and serotonin re- } \\
\text { uptake restraint. }\end{array}$ & $4.45 \mathrm{~kg}$ at 1 year & $\begin{array}{l}\text { Headache, insomnia, dry } \\
\text { mouth and constipation. } \\
\text { Long term treatment } \\
\text { increases the risk of } \\
\text { heart attack and stroke. }\end{array}$ \\
\hline $\begin{array}{l}\text { Orlistat } \\
\text { (xencial) }\end{array}$ & Lipase inhibitor decreases fat retention. & $\begin{array}{l}2.59 \mathrm{~kg} \text { at } \\
6 \text { months and } \\
2.89 \mathrm{~kg} \text { at } 1 \text { year }\end{array}$ & $\begin{array}{c}\text { Diarrhea, flatulence, } \\
\text { bloating, abdominal } \\
\text { pain, } \\
\text { and dyspepsia }\end{array}$ \\
\hline $\begin{array}{l}\text { Rimonabant } \\
\text { (Acomplia) }\end{array}$ & $\begin{array}{c}\text { Particular CB1 receptor blocker diminishes } \\
\text { nourishment admission }\end{array}$ & $51 \mathrm{~kg}$ at 1 year & $\begin{array}{c}\text { Nausea, dizziness, } \\
\text { arthralgia, and diarrhea }\end{array}$ \\
\hline
\end{tabular}

Table 2 Some common anti-obesity drugs.(73)

\subsection{Diuretics}

Diuretics cause misfortune of liquids that will result in slow weight reduction. Diuretics cause brief weight misfortune with no loss in body fat. Their utilize ought to be maintained a strategic distance from due to the genuine side effect of electrolytes imbalance. $(68,69)$

\subsection{Surgical treatment for obesity}

Bariatric or Weight Misfortune Surgery (WLS) was already categorized as malabsorptive, prohibitive, or a combination of both. However with a more prominent understanding of the extensive neural-hormonal impacts of WLS on satiety, starvation and digestion system, the over specified wide categories are no longer appropriate. In reality, nowadays Bariatric or WLS is maybe better referred to as Metabolic Surgery. The foremost common metabolic surgical methods incorporate Roux-en-Y gastric bypass, movable gastric band, sleeve gastrectomy, and biliopancreatic diversion.(70) The National Established of Wellbeing agreement has proposed the taking after rules for surgery in obese patients:

A. Patients with BMI more than 40.

B. Patients with BMI more than 35 who have genuine therapeutic issues such as rest apnea, that would be improved with weight misfortune.

\subsection{Natural products for treatment of obesity}

The potential of characteristic items for treating weight is under exploration. This may be an fabulous elective technique for developing future viable, secure anti-obesity drugs.(71) A assortment of characteristic items, counting unrefined extricates and separated pure natural compounds can actuate body weight lessening and anticipate diet-induced corpulence. In this manner, they have been broadly utilized in treating obesity.(72)

\subsubsection{Dietary phytochemicals}

Dietary phytochemicals could be utilized as anti-obesity agents since they may smother the development of the adipose tissue, restrain separation of preadipocytes, stimulate lipolysis, and initiate apoptosis of existing adipocytes, thereby reducing fat tissue mass(Table 3 and Fig. 2). (73)

\begin{tabular}{|l|l|l|}
\hline Phytochemical & \multicolumn{1}{|c|}{ Examples } & \multicolumn{1}{c|}{ Side-Effects } \\
\hline Polyphenols & $\begin{array}{l}\text { Simple phenolic acids } \\
\text { (e,g ferulic,caffcic) }\end{array}$ & $\begin{array}{l}\text { Ferulic corrosive has hypolipidemic impact and brings down the chance } \\
\text { of tall fat diet-induced obesity and decreases serum cholesterol } \\
\text { Stilbenes(resveratrol) } \\
\text { Resveratrol diminishes LDL-cholesterol and anticipates lipid oxidation } \\
\text { Decreases adipogenesis by downregulating adipocyte translation } \\
\text { components, modifying the expression of adipocyte particular genes } \\
\text { In develop adipocytes, it increments lipolysis, actuates apoptosis, and } \\
\text { diminishes lipogenesis, proliferation and lipid accumulation Dietary } \\
\text { supplements of resveratrol, vitamin D, quercetin, and genistein decrease } \\
\text { weight gain and body fat driving to potential novel treatments for } \\
\text { obesity }\end{array}$ \\
& Curcumins & $\begin{array}{l}\text { Anticipate lipid accumulation Regulate vitality digestion system and } \\
\text { diminish level of intracellular lipids In fat tissues, curcumins stifle } \\
\text { angiogenesis vital for tissue growth Curcumins control translation } \\
\text { variables that play key parts in adipo- and lipogenesis }\end{array}$ \\
\hline
\end{tabular}


International Journal of Trend in Scientific Research and Development (IJTSRD) @ www.ijtsrd.com eISSN: 2456-6470

\begin{tabular}{|c|c|c|}
\hline & $\begin{array}{l}\text { Liganas } \\
\text { secoisolariciresinol, } \\
\text { matairesional) }\end{array}$ & $\begin{array}{l}\text { They are changed over to mammalian lignans enterodiol and } \\
\text { enterolactone which will reduce the hazard of inveterate illnesses } \\
\text { counting obesity } \\
\text { Weaken in vitro adipogenesis by actuating AMPK flag pathway in } \\
\text { preadipocytes and diminishing expression of adipogenesis related } \\
\text { factors }\end{array}$ \\
\hline Alkaloids & $\begin{array}{l}\text { Ephedrine } \\
\text { Caffeien } \\
\text { Nicotine }\end{array}$ & $\begin{array}{l}\text { Weakens obesity-induced aggravation, weight related metabolic } \\
\text { clutters, and liver diseases Reduces nourishment admissions and } \\
\text { increments vitality consumption and lipid oxidation } \\
\text { Increases norepinepherine causing craving suppression } \\
\text { Produces thermogenic impact (increment basal metabolic rate) and } \\
\text { vitality expenditure Fortifies fat breakdown, potentiates the anorectic } \\
\text { and thermogenic impacts in addition to its diuretic effect } \\
\text { Diminishes nourishment admissions and increments fat oxidation and } \\
\text { vitality expenditure }\end{array}$ \\
\hline Terpenoids & $\begin{array}{l}\text { Abscisic Acid(ABA) } \\
\text { Carotenoids } \\
\text { Lycopene }\end{array}$ & $\begin{array}{l}\text { Compelling in treatment of diabetes and obesity-related inflammation } \\
\text { Carotenoids may anticipate aggravation related infections such as } \\
\text { corpulence and atherosclerosis } \\
\text { Lycopene wealthy diets lower the hazard of CVD (restraint of LDL } \\
\text { oxidation and lipid peroxidation) }\end{array}$ \\
\hline Organosulfur & Ajoene & $\begin{array}{l}\text { Diminishes cholesterol amalgamation, brings down blood weight, and } \\
\text { fortifies non-specific immunity } \\
\text { Decreases fat cell number proposing a few restorative plausibility for } \\
\text { obesity }\end{array}$ \\
\hline Phytosterols & $\begin{array}{l}\text { Diosgenin } \\
\text { Brassicastero } \\
\text { Sitosterol } \\
\text { protodioscin } \\
\text { Diosgenin }\end{array}$ & $\begin{array}{l}\text { Tall immaterial of these sterols can secure against atherosclerosis and } \\
\text { diminish LDLcholesterol } \\
\text { Trend in Scientific } \\
\text { Phytosterols compete with cholesterol for micelle arrangement within } \\
\text { the intestinal lumen and inhibit cholesterol absorption } \\
\text { Essentially diminishes blood levels of TG, cholesterol, LDL and } \\
\text { increments high-density lipoproteins } \\
\text { Restrains collection of TG and expression of lipogenic genes }\end{array}$ \\
\hline
\end{tabular}

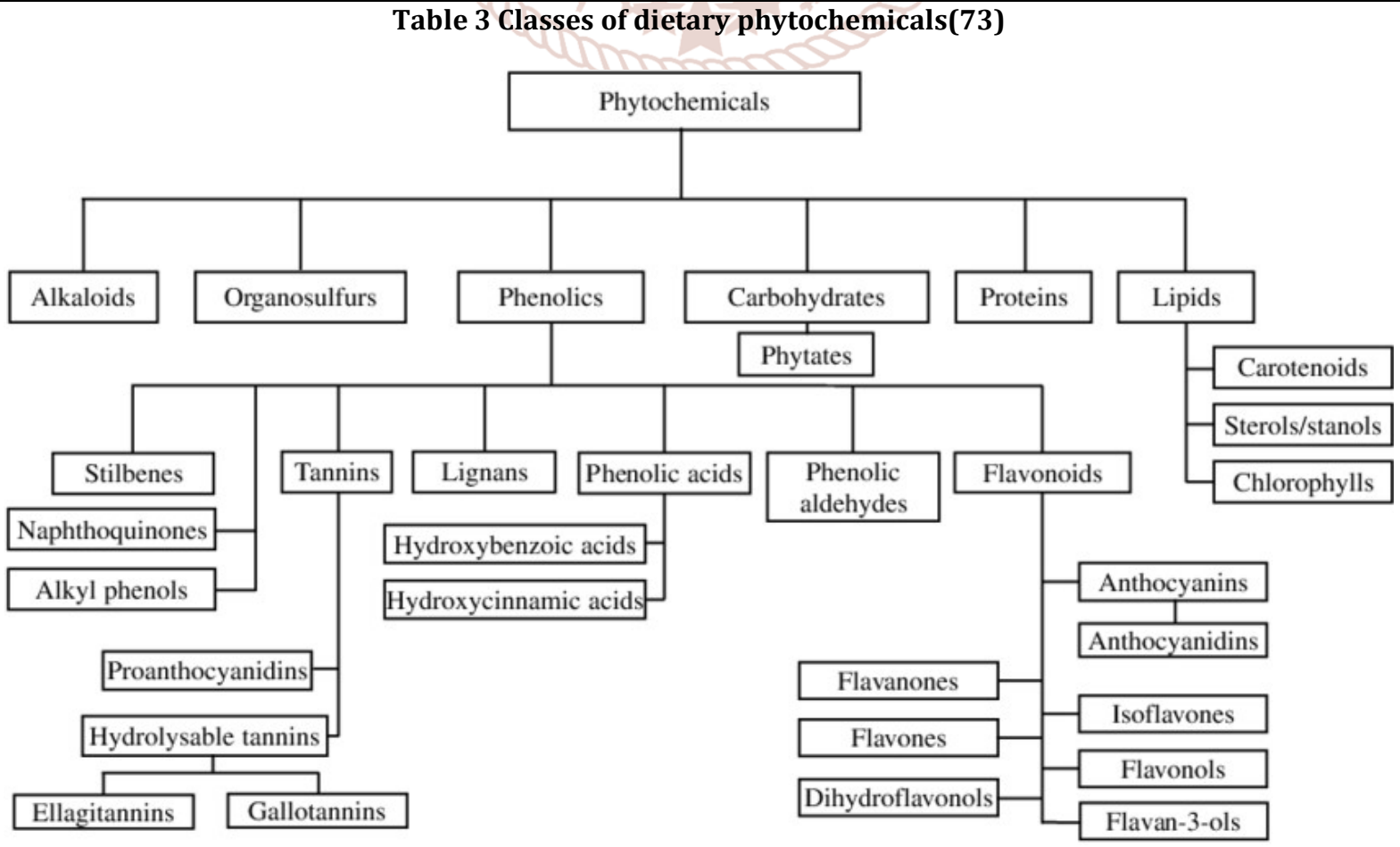

Figure 2 Classification of common dietary phytochemicals. 


\subsubsection{Natural products}

\subsubsection{Natural products with lipase inhibitory effect.}

Dietary fat is ingested by the digestive system when it has been subjected to the activity of pancreatic lipases. Pancreatic lipase may be a key enzyme in dietary triacylglycerol retention, hydrolyzing triacylglycerols to monoacylglycerols and greasy acids. Few Few substances connected straightforwardly with the lipases as orlistat. It is a derivative of the naturallyoccurring lipase inhibitor from Streptomyces toxytricini. (74) Orlistat represses by shaping a covalent bond to the lipase's serine dynamic site.(75) In spite of the fact that it is clinically endorsed for weight treatment, it has certain unpleasant gastrointestinal side-effects.(76) Normal items give a tremendous pool of pancreatic lipase inhibitors.(77) A wide assortment of plant items such as saponins, polyphenols, flavonoids, and caffeine have lipase inhibitory impacts (Table 4).(78)

\begin{tabular}{|l|l|}
\hline \multicolumn{1}{|c|}{ Source } & \multicolumn{1}{|c|}{ Used part and/or active constituents } \\
\hline Panax japonicus (rhizomes) & Chikusetsusaponins \\
Thea sinensis (oolong tea & Crude aqueous extract (caffeine) \\
Cassia mimosoides & Proanthocyanidin \\
Trigonella foenum graecum L. (seed) & Crude ethanolic extract \\
Salix matsudana (leaf) & Polyphenol (PP) \\
Vitis vinifera & Crude ethanolic extract \\
Salvia officinalis L. (leaf) & Methanolic extract (carnosic acid) \\
Cassia nomame & Flavan dimers \\
Coffea canephora & Caffeine, chlorogenic acid, neochlorogenic, and feruloylquinic acids \\
Citrus unshiu & Hesperidin \\
Chitosan-chitin & Chitosan (80\%), chitin (20\%) \\
Streptomyces toxytricini (fungus) & Lipistatin \\
Actinomycetes sp. & Valilactone \\
Caulerpa taxifolia (marine algae) & Caulerpenyne \\
\hline
\end{tabular}

Table 4 Natural pancreatic lipase inhibitors(73)

\subsubsection{Natural appetite suppressants.}

Body weight regulation through appetite control is a multifactorial event resulting from neurological and hormonal interrelationships. A line of evidence indicates that serotonin, histamine, dopamine, and their associated receptor activities are closely associated with satiety regulation. These receptors may enable better targets for drugs treating obesity through energy intake reduction.(79) Agents that act via peripheral satiety peptide systems alter the various hypothalamic neuropeptide levels. Also, they alter the key CNS appetite monoamine neurotransmitter levels and may be suitable candidates for appetite suppressants.(80) Natural ()-hydroxycitric acid (HCA) from Garcinia cambogia, is a potential natural appetite suppressant. It is available under the names HCA-SX and Super CitriMax. (81) Hypericum perforatum increases the serotonin quantity present within synaptosomes by inhibiting synaptosomal uptake of serotonin, which suppresses the appetite and reduces food intake. Thus increased serotonergic transmission might be the link between antidepressant and anti-obesity activities of $\mathrm{H}$. perforatum. (82) Some natural appetite suppressants are listed in Table 5

\begin{tabular}{|c|c|}
\hline Source & Used part and/or active constituents \\
\hline Panax ginseng (root) & Crude saponins \\
\hline Garcinia cambogia & ()-Hydroxycitric acid (HCA) \\
\hline Camellia sinensis (leaf) & O-Epigallo-cathechin gallate (EGCG) \\
\hline Hoodia gordonii andH. pilifera & Steroidal glycoside (P57AS3) \\
\hline Phaseolus vulgaris and & Lectins \\
\hline Robinia pseudoacacia & Pinus koraiensis \\
\hline Pinus koraiensis(pine nut) & Pine nut fatty acids \\
\hline Ephedra species & Ephedrine \\
\hline Citrus aurantium & Synephrine \\
\hline Hypericum perforatum & Total extract \\
\hline
\end{tabular}

Table 5 Examples of natural appetite suppressants (73)

\subsubsection{Natural energy expenditure stimulants}

Over the top adiposity comes about from vitality lopsidedness, where the consequences of intemperate nourishment admissions are not adjusted by expanding energy expenditure. Vitality use has numerous components, and can be classified into physical movement, compulsory energy expenditure, and versatile thermogenesis.(83) For case, the ethan olic extricate of Solanum tuberosum enacted the expression of UCP(Upcoupling protein) in BAT and the liver, and significantly diminished fat weight.(84) 2 Numerous common compounds have been proposed as medications for weight by means of enhanced energy use counting caffeine, capsaicin, and green tea and its extract.(85)

\subsubsection{Natural adipocyte differentiation inhibitors}

Adipocytes play a central part within the mainten ance of lipid homeostasis and vitality adjust by putting away triglycerides and discharging free greasy acids in reaction to alter in vitality demands.(86) Common items particularly polyunsaturated greasy acids (PUFA) act as flag transducing molecules in adipocyte differentiation. In this way, PUFA play a central part in stifling lipogenesis and directing adipocyte differentiation through concealment of late-phase adipocyte differentiation.(87) Illustrations of a few common items with adipocyte differentiation inhibitory impact are given in Table 6. 
International Journal of Trend in Scientific Research and Development (IJTSRD) @ www.ijtsrd.com eISSN: 2456-6470

\begin{tabular}{|l|l|}
\hline \multicolumn{1}{|c|}{ Source } & Used part and/or active constituents \\
\hline Garcinia cambogia & O-Hydroxycitric acid (HCA) \\
Glycine max (product of GIBCO) & Genistein \\
Chili pepper (Capsicum) & Capsaicin \\
Fish oil & Docosahexaenoic acid \\
Palm oil & y-tocotrienol \\
Sterol (product of Sigma) & 3-sitosterol \\
Camellia sinensis (green tea) & O-Epigallocatechin gallate \\
Panax ginseng & Ginsenosides \\
Silybum marianum & Silibinin \\
Garlic & Ajoene \\
Rosmarinus officinalis & Carnosic acid \\
Curcuma longa & Curcumin \\
Humulus lupulus & Xanthohumol \\
\hline
\end{tabular}

Table 6 Natural adipocyte differentiation inhibitors.(73)

\subsubsection{Natural lipid metabolism regulators}

The pharmacological focusing on of lipolysis can be achieved by invigorating triglyceride hydrolysis in arrange to diminish fat stores, in this manner combating weight. The flavonoids from Nelumbo nucifera clears out are illustrations of the natural products included in b-adrenergic receptor activation.(88) Table 7 appears cases of common items, which promote lipid digestion system.

\begin{tabular}{|c|c|}
\hline Source & Used part and/or active constituents \\
\hline Morus albam, Melissa officinalis, Artemisia & Crude aqueous extract \\
\hline capillaries (leaf) & \\
\hline Curcuma longa L. & $\mathrm{Cu}$ \\
\hline Glycyrrhiza glabra L. (root) & Licorice flavonoid \\
\hline Panax ginseng & $\begin{array}{l}\text { Crude aqueous extract } \\
\text { Trend in Scientific }\end{array}$ \\
\hline Zea mays L. & Purple corn color (anthocyanins) \\
\hline Soybean & Genistein and L-carnitine (soy isoflavone) \\
\hline Coffea canephora & Caffeine, chlorogenic, neochlorogenic, and feruloyquinic acids \\
\hline
\end{tabular}

Table 7 Natural lipid metabolism regulators (73)

\subsubsection{Marine natural products}

Iodine is the foremost important active component in Fucus vesiculosus, too it contains polyphenols, polysaccharides, sterols, and other minerals. Iodine is known to play an critical part within the treatment of corpulence. Iodine was accepted to fortify the thyroid gland, causing weightloss. $(89,90)$ Astaxanthin, a xanthophyll carotenoid, separated the marine algae Haematococcus pluvialis, Chlorella zofingiensis, and Chlorococcum sp. was found to repress the increments in body weight and weight of the fat tissue, though diminish liver weight, liver triglyceride, plasma triglyceride, and total cholesterol.(91) Krill oil is extricated from Antarctic krill, Euphausia superba, a zooplankton shellfish wealthy in phospholipids carrying long-chain omega-3 PUFAs, basically EPA and DHA. Furthermore, Krill oil too contains different potent antioxidants, counting vitamins A and E and astaxanthin.(92) It has been detailed that krill oil seem decrease the level of glucose, add up to cholesterol, triglycerides, LDL and HDL, and could increase plasma eicosapentaenoic corrosive (EPA) and docosahexaenoic corrosive (DHA), with no sign of antagonistic impacts on safety parameters. $(92,93)$

\section{CONCLUSION}

Weight administration may be a life-long process and permanent weight decrease is troublesome to realize. The extreme cause of obesity is an lopsidedness between calorie admissions and energy expenditure resulting from complex intelligent between many genetic and natural variables. Corpulence could be a incessant disease that influences millions of individuals around the world and contributes to substantial horribleness and mortality. A fruitful weight control program must adjust calorie admissions with energy expenditure. Count calories and work out have been the pillars for weight control. Common items can play a secure and effective role with corpulence extraordinarily those containing filaments, polyphenols, sterols, and alkaloids. In expansion, they are a great supplement for vitamins and minerals. In common, common items with potential activity in treatment of weight act as a common body cleanser, direct digestion system, break up fat within the body, help to kill longing for of nourishment, invigorate glandular secretions, reduce water maintenance, boot vitality and offer assistance in constipation. However, their utilize ought to be in conjunction with regular exercise, as well as dietary and behavioral adjustments. The use of numerous phytochemicals might result in synergistic and improved impacts. 
International Journal of Trend in Scientific Research and Development (IJTSRD) @ www.ijtsrd.com eISSN: 2456-6470

\section{REFERENCE}

[1] World Health Organization. Obesity: preventing and managingthe global epidemic report of a WHO consultation on obesity.WHO: Geneva, Switzerland; 1998.

[2] Popkin BM. The world is fat: the fads, trends, policies, andproducts that are fattening thehuman race. New York: AveryTrade/Penguin Group; 2009.

[3] Singla P, Bardoloi A, Parkash AA. Metabolic effects of obesity: areview. World J Diabetes 2010

[4] Derdemezis CS, Voulgari PV, Drosos AA, Kiortsis DN. Obesity,adipose tissue andrheumatoid arthritis: coincidence or morecomplex relationship? Clin Exp Rheumatol 2011;29:712-27.

[5] Withrow D, Alter DA. The economic burden of obesityworldwide: a systematic review ofthe direct costs of obesity.Obes Rev 2011

[6] Popkin BM, Kim S, Rusev ER, Du S, Zizza C. Measuring the fulleconomic costs of diet, physical activity and obesity-relatedchronic diseases. Obes Rev 2006

[7] Timar R, Obezitatea adultului, Serban V, Babes PA. ClinicaMedicala. Teorie si practica, Editura de Vest, Timisoara; 1999, p.83-198.

[8] Aronne LJ. Classification of obesity and assessment of obesityrelated health risks. Obes Res 2002

[9] Ordova's JM, Shen J. Gene-environment interactions and susceptibility to metabolic syndrome and other chronic diseases. J

Periodontol 2008

[10] International Obesity Task Force TIOTF. http://www.iotf.org/.

[11] Marti A, Martinez-Gonza'lez MA, Martinez JA. Interactionbetween genes and lifestyle factors on obesity. Proc Nutr Soc2008

[12] Pe'russe L, Bouchard C. Gene-diet interactions in obesity. Am SocClin Nutr 2000

[13] World Health Organization. Global strategy on diet physicalactivity and health. WHO: Geneva, Switzerland; 2007.

[14] Santos AP, Rogero MM, Bastos DH. Edible plants, theirsecondary metabolites and antiobesogenic potential. Recent PatFood Nutr Agric 2010;2:195-212.

[15] Rayalam S, Della-Fera MA, Baile CA. Phytochemicals andregulation of the adipocyte life cycle. J Nutr Biochem 200816. Liu RH. Health benefits of fruit and vegetables are from additiveand synergistic combinations of phytochemicals. Am J Clin Nutr2003

[16] Online Etymology Dictionary: Obesity. Douglas Harper.

[17] Physical Status: The Use and Interpretation of Anthropometry.WHO Technical Report Series 854:9.

[18] Brown JE, Potter JD, Jacobs DR, Kopher RA, Rourke MJ,et al. Maternal waist-to-hip ratio as a predictor of newborn size:results of the diana project. Epidemiology 1996;7:62-6.

[19] Lau DC, Douketis JD, Morrison KM, Hramiak IM, SharmaAM. Obesity canada clinical practice guidelines expert panel.CMAJ 2007

[20] Bleich S, Cutler D, Murray C, Adams A. Why is the developedworld obese? Annu Rev Public Health 2008
[21] James WP. The fundamental drivers of the obesity epidemic.Obes Rev 2008

[22] Keith SW, Redden DT, Katzmarzyk PT. Putative contributors tothe secular increase in obesity: exploring the roads less traveled.Int J Obes 2006

[23] Flegal KM, Carroll MD, Ogden CL, Johnson CL. Prevalenceand trends in obesity among U.S. adults. JAMA 2002;288:1723-7.

[24] Ness-Abramof R, Apovian CM. Diet modification for treatmentand prevention of obesity. Endocrine 2006;29:5-9.

[25] Salmon J, Timperio A. Prevalence, trends and environmentalinfluences on child and youth physical activity. Med Sport Sci2007;50:183-99.

[26] Loos RJ, Bouchard C. FTO: the first gene contributing tocommon forms of human obesity. Obes Rev 2008

[27] Farooqi IS, Keogh JM, Yeo GSH, Lank EJ, Cheetham T, et al.Clinical spectrum of obesity and mutations in the melanocortin 4 receptor gene. Engl J Med 2003

[28] Nothen MM, Cichon S, Hemmer S, Hebebrand J, Remschmidt $\mathrm{H}$, et al. Human dopamine D4 receptor gene: frequent occurrence of a null allele and observation of homozygosity. Hum MolGenet 1994

[29] Ristow M, Muller-Wieland D, Pfeiffer A, Krone W, Kahn CR.Obesity associated with a mutation in a genetic regulator ofadipocyte differentiation. $\mathrm{N}$ Engl J Med 1998

[30] Campfield LA, Smith FJ, Rosenbaum M, Hirsch J. Humaneating: evidence for a physiological basis using a modifiedparadigm. Neurosci Biobehav Rev 1996

[31] Rose'n T, Bosaeus I, To"lli J, Lindstedt G, Bengtsson BA.Increased body fat mass and decreased extracellular fluid volumein adults with growth hormone deficiency. Clin Endocrinol1993

[32] Haslam DW, James WP. Obesity. Lancet 2005

[33] Chiles C, Van Wattum PJ. Psychiatric aspects of the obesitycrisis. Psychiatr Times 2010

[34] Yach D, Stuckler D, Brownell KD. Epidemiologic and economicconsequences of the global epidemics of obesity and diabetes. NatMed 2006

[35] Sobal J, Stunkard AJ. Socioeconomic status and obesity: a review of the literature. Psychol Bull 1989

[36] Chiolero A, Faeh D, Paccaud F, Cornuz J. Consequences ofsmoking for body weight, body fat distribution, and insulinresistance. Am J Clin Nutr 2008

[37] Di-Baise JK, Zhang H, Crowell MD, Krajmalnik-Brown R,Decker GA, et al. Mayo Clinic proceedings. Gut microbiota andits possible relationship with obesity. Mayo Clin 2008

[38] Palou M, Sanchez J, Rodriguez AM, Priego T, Pico C, et al.Induction of NPY/AgRP orexigenic peptide expression in rathypothalamus is an early event in fasting: relationship withcirculating leptin, insulin and glucose. Cell Physiol Biochem 2009

[39] Hamann A, Matthaei S. Regulation of energy balance by leptin.Exp Clin Endocrinol Diabetes 1996

[40] Flier JS. Obesity wars: molecular progress confronts an expanding epidemic. Cell 2004;116(2):337-50. 
International Journal of Trend in Scientific Research and Development (IJTSRD) @ www.ijtsrd.com eISSN: 2456-6470

[41] Wren AM, Bloom SR. Gut hormones and appetite control.Gastroenterology 2007;132(6):2116-30.

[42] Kumanyika SK, Obarzanek Eva, Stettler N, Bell R, Field AE,et al. Population-based prevention of obesity:, Interdisciplinary Committee for Prevention (formerly theexpert panel onpopulation and prevention science). Circulation 2008

[43] Klein S, Burke LE, Bray GA.: endorsed by theAmerican College of Cardiology Foundation. Circulation2004

[44] Rock CL, Flatt SW, Sherwood NE, Karanja N, Pakiz B, et al.Effect of a free preparedmeal and incentivized weight lossprogram on weight loss and weight lossmaintenance in obese andoverweight women: a randomized controlled trial. JAMA 2010

[45] Anon C. Position of the American Dietetic Association: healthimplications of dietary fiber. J Am Diet Assoc 1997

[46] Rosenbaum M, Leibel R, Hirsch J. Obesity. N Engl J Med 1997

[47] Spiegelman BM, Flier JS. Obesity and the regulation of energybalance. Cell 2001

[48] Blair SN, Brodney S. Effects of physical inactivity and obesity onmorbidity and mortality: current evidence and research issues. Med Sci Sports Exerc 1999

[49] Stevens J, Evenson KR, Thomas O, Cai J, Thomas R. Associations of fitness and fatnesswith mortality in Russian andAmerican men in the lipids research clinics study. Int JObesRelat Metab Disord 2004

[50] Smith IG, Goulder MA. Randomized placebo-controlled trial oflong-term treatment with sibutramine in mild to moderateobesity. J Fam Pract 2001

[51] Li MF, Cheung BM. Rise and fall of anti-obesity drugs. World J Diabetes 2011

[52] Hardman JG, Limbird LE, Molinoff PB, Ruddon RW. Gilman'sAG the pharmacological basis of therapeutics. 9th ed. NewYork: McGraw-Hill; 2008.

[53] Lewis W, Elvin-Lewis M. Medical botany, plants affecting man'shealth. New York: Johan Wiley and Sons Inc.; 1977.

[54] Kissane NA, Pratt JSA. Medical and surgical treatment ofobesity. Best Pract Res Clin Anaeshesiol 2011

[55] Mayer MA, Hocht C, Puyo A, Taira CA. Recent advances inobesity pharmacotherapy. Curr Clin Pharmacol 2009

[56] Han LK, Kimura Y, Okuda H. Anti-obesity effects of naturalproducts. Stud Nat Prod Chem 2005

[57] Bulletin of Faculty of Pharmacy, Cairo University (Gamal A. Mohamed a, Sabrin R.M. Ibrahim b, *, Ehab S. Elkhayat a , Riham Salah El Dine)

[58] Ballinger A, Peikin SR. Orlistat: its current status as an antiobesity drug. Eur J Pharmacol 2002

[59] Tsujita T, Takaichi H, Takaku T, Aoyama S, Hiraki J.Antiobesity action of epsilon-polylysine, a potent inhibitor ofpancreatic lipase. J Lipid Res 2006

[60] Karamadoukis L, Shivashankar GH, Ludeman L, Williams AJ.An unusual complication of treatment with orlistat. Clin Nephrol2009

[61] Birari RB, Bhutani KK. Pancreatic lipase inhibitors from naturalsources: unexplored potential. Drug Discov Today 2007
[62] Shimoda H, Seki E, Aitani M. Inhibitory effect of green coffeebean extract on fat accumulation and body weight gain in mice.BMC Complement Altern Med 2006

[63] Chantre P, Lairon D. Recent findings of green tea extract AR25(Exolise) and its activity for the treatment of obesity. Phytomedicine 2002;9:3-8.128. Wynne K, Stanley S, McGowan B, Bloom S. Appetite control. JEndocrinol 2005.

[64] Wynne K, Stanley S, McGowan B, Bloom S. Appetite control. J Endocrinol 2005.

[65] Ohia SE, Opere CA, LeDay AM, Bagchi M, Bagchi D, et al.Safety and mechanism of appetite suppression by a novelhydroxycitric acid extract (HCA-SX). Mol Cell Biochemistry

[66] Husain GM, Chatterjee SS, Singh PN, Kumar V. Hypolipidemic and antiobesity-like activity of standardized extract of Hypericum perforatum L. in rats. Int Scholarly Res Network Pharmacol 2011

[67] Redinger RN. Fat storage and the biology of energy expenditure.Transl Res 2009

[68] Yoon SS, Rhee YH, Lee HJ, Lee EO, Lee MH, et al. Uncoupled protein 3 and p38 signal pathways are involved in anti-obesity activity of Solanum tuberosum L. cv. Bora Valley. J Ethnopharmacol 2008

[69] Rayalam S, Della-Fera MA, Baile CA. Phytochemicals and regulation of the adipocyte life cycle. J Nutr Biochem 2008;19:717-26.

[70] Kim HK, Della-Fera M, Lin J, Baile CA. Docosahexaenoic acidinhibits adipocyte differentiation and induces apoptosis in 3T3-L1 preadipocytes. J Nutr 2006

[71] Madsen L, Petersen RK, Kristiansen K. Regulation of adipocytedifferentiation and function by polyunsaturated fatty acids.Biochim Biophys Acta 2005

[72] Ohkoshi E, Miyazaki H, Shindo K, Watanabe H, Yoshida A,et al. Constituents from the leaves of Nelumbo nucifera stimulatelipolysis in the white adipose tissue of mice. Planta Med 2007

[73] Leite-Silva C, Gusmão CLS, Takahashi CS. Genotoxic andantigenotoxic effects of Fucus vesiculosus extract on culturedhuman lymphocytes using the chromosome aberration andComet assays. Genet Mol Biol 2007

[74] Chojnacka K, Saeid A, Witkowska Z, Tuhy L. Biologically activecompounds in seaweed extracts-the prospects for the application.Open Conf Proceed J 2012

[75] Wang H, Fu Z, Han C. The potential applications of marinebioactives against diabetes and obesity. Am J Mar Sci 2014; 184. Bunea R, El Farrah K, Deutsch L. Evaluation of the effects ofneptune krill oil on the clinical course of hyperlipidemia. AlternMed Rev 2004;

[76] Bunea R, El Farrah K, Deutsch L. Evaluation of the effects of neptune krill oil on the clinical course of hyperlipidemia. Altern Med Rev 2004

[77] Maki KC, Reeves MS, Farmer M, Griinari M, Berge K, et al.Krill oil supplementation increases plasma concentrations ofeicosapentaenoic and docosahexaenoic acids in overweight andobese men and women. Nutr Res 2009; 